\title{
O DOPUSZCZALNOŚCI WZNOWIENIA POSTĘPOWANIA KARNEGO Z POWODU ORZECZENIA EUROPEJSKIEGO TRYBUNAŁU PRAW CZŁOWIEKA STWIERDZAJĄCEGO NARUSZENIE PRAW CZŁOWIEKA W PODOBNEJ SPRAWIE
}

Temat wznowienia postępowania karnego wskutek orzeczenia Europejskiego Trybunału Praw Człowieka (dalej: ETPCz) był już przedmiotem licznych wypowiedzi przedstawicieli doktryny prawa karnego procesowego ${ }^{1}$. Jednym ze spornych zagadnień w obrębie tej tematyki pozostaje wciąż to, czy dopuszczalne jest wznowienie postępowania karnego na wniosek osoby, która nie uzyskała korzystnego dla siebie rozstrzygnięcia ETPCz, a jedynie uważa, że w dotyczącym jej postępowaniu karnym miało miejsce podobne naruszenie Konwencji o ochronie praw człowieka i podstawowych wolności ${ }^{2}$, jak to stwierdzono w orzeczeniu strasburskim. Ujmując rzecz inaczej, sporne jest, czy wznowienie postępowania w trybie określonym w art. $540 \S 3$ k.p.k. powinno następować na podstawie orzeczenia strasburskiego (co obligowałoby składającego wniosek do wskazania orzeczenia ETPCz odnoszącego się do postępowania karnego prowadzonego wobec niego ${ }^{3}$ ), czy też z powodu orzeczenia strasburskiego wydanego w innej sprawie, a może nawet przeciwko innemu państwu-stronie Konwencji.

W doktrynie zdecydowanie przeważa stanowisko o dopuszczalności wznowienia postępowania na podstawie art. $540 § 3$ k.p.k. również w innych sprawach karnych niż ta, której dotyczy orzeczenie ETPCz. Słusznie wyróżnia się dwa rodzaje orzeczeń strasburskich: rozstrzygnięcia identyfikujące sprzeczność prawa krajowego z postanowieniami Konwencji oraz rozstrzygnięcia wskazujące jedynie na

Por. m.in.: P. Hofmański, Nowe polskie prawo karne w świetle europejskich standardów w zakresie ochrony praw człowieka, Warszawa 1997, s. 67-68; A. Bojańczyk, Podważenie prawomocnego wyroku sądu karnego przez Europejski Trybunał Praw Człowieka w Strasburgu (ETPCz). Próba zarysu zagadnienia - cz. II, „Palestra” 2001, nr 7-8, s. 124-133; M. Wąsek-Wiaderek, Wznowienie postępowania karnego w następstwie wyroku Europejskiego Trybunału Praw Człowieka, Studia i Analizy Sądu Najwyższego, tom IV, K. Ślebzak (red.), Warszawa 2010, s. 277-304; B. Nita, Orzeczenie ETPCz jako podstawa wznowienia postępowania karnego, „Europejski Przegląd Sądowy" 2010, nr 9, s. 4-10; S. Zabłocki, Wznowienie postępowania w sprawach karnych po orzeczeniu Europejskiego Trybunału Praw Człowieka, „Krajowa Rada Sądownictwa” 2013, nr 1, s. 27-34.

2 Dz.U. z 1993 r. Nr 61, poz. 284, z późniejszymi zmianami; dalej powoływana jako „Konwencja” lub „EKPCz”.

3 Sprawa, której dotyczy orzeczenie strasburskie będzie dalej określana mianem „sprawy głównej”. 
nieprawidłowe stosowanie przepisów krajowych, powodowane przeprowadzeniem ich nieprawidłowej wykładni, nieuwzględniającej kontekstu konstytucyjnego i konwencyjnego ${ }^{4}$. W odniesieniu do pierwszej grupy orzeczeń wyrażana jest potrzeba poszukiwania środka prawnego skutkującego zmianą przepisów krajowych. A. Bojańczyk proponuje zastosowanie instytucji pytania prawnego przez sąd orzekający w ponownym postępowaniu karnym, po uchyleniu prawomocnego orzeczenia na podstawie art. $540 \S 3$ k.p.k. ${ }^{5}$ B. Nita, uznając niedopuszczalność wystąpienia z pytaniem prawnym do Trybunału Konstytucyjnego w takim układzie procesowym, proponuje jednocześnie uruchomienie innych środków prawnych, mianowicie abstrakcyjnej kontroli zgodności przepisu prawa z Konstytucją lub Konwencją. Należy stanowczo zgodzić się z poglądem, że to przede wszystkim do ustawodawcy należy dbanie o zgodność przepisów ustawowych z Konwencją ${ }^{6}$. Sądy powinny uczestniczyć $\mathrm{w}$ wykonaniu orzeczeń strasburskich $\mathrm{w}$ takim zakresie, $\mathrm{w}$ jakim pozwalają im na to ich kompetencje. Nie ma zatem wątpliwości, że powinny traktować orzeczenie strasburskie jako ograniczające ich samodzielność jurysdykcyjną i uznawać się za związane wykładnią Konwencji zawartą w orzecznictwie ${ }^{7}$. Nie oznacza to jednak, że takie związanie przydaje im kompetencji i jednocześnie odpowiedzialności za likwidowanie kolizji norm ustawowych i konwencyjnych. Toteż trudno wskazać podstawy dla odmiennego traktowania pierwszej grupy orzeczeń na gruncie art. $540 \S 3$ k.p.k. jak tych, w których ma miejsce niezgodne z Konwencją zastosowanie przepisów prawa.

Jak już wspomniano, w piśmiennictwie dominuje pogląd o dopuszczalności wznowienia postępowania na podstawie art. $540 \S 3$ k.p.k. także w innych podobnych sprawach. Jego zwolennicy zastrzegają jednak, że może to nastąpić jedynie „W ograniczonym zakresie”, jeżeli ,jest oczywiste, że z uwagi na analogiczny układ okoliczności faktycznych i takie same uwarunkowania prawne, jak występujące w sprawie, w której zapadło rozstrzygnięcie organu międzynarodowego, jest rzeczą niemal pewną, że także oskarżony uzyskałby potwierdzenie swoich racji w postępowaniu przed tym organem"s. Podstawowym argumentem podnoszonym na po-

Tak: A. Bojańczyk, Podważenie..., op. cit., cz. II, s. 125; B. Nita, Orzeczenie..., op. cit., s. 5.

A. Bojańczyk, Podważenie..., op. cit., cz. II, s. 127-128.

B. Nita, Orzeczenie..., op. cit., s. 6.

O rodzajach orzeczeń strasburskich, które wiążą sądy karne oraz zakresie tego związania szerzej, (w:) M. Wąsek -Wiaderek, Samodzielność jurysdykcyjna sądu karnego wobec kompetencji Trybunału Konstytucyjnego i trybunałów europejskich, Lublin 2012, s. 349-393.

P. Hofmański, E. Sadzik, K. Zgryzek, Kodeks postępowania karnego. Komentarz, tom III, P. Hofmański (red.), Warszawa 2012, s. 391-392; Podobnie: S. Zabłocki, (w:) R.A. Stefański, S. Zabłocki (red.), Kodeks postępowania karnego. Komentarz, tom III, Warszawa 2004, s. 673; tenże, Wznowienie..., op. cit., s. 32; A. Bojańczyk, Podważenie..., op. cit., cz. 2, s. 131; B. Nita, Orzeczenie..., op. cit., s. 7; D. Świecki, (w:) Kodeks postępowania karnego. Komentarz, tom II, D. Świecki (red.), Warszawa 2013, s. 821 (Autor dopuszcza wznowienie poza sprawą główną wyłącznie w sytuacji, gdy naruszenie Konwencji stwierdzone w wyroku ETPCz wskazuje na niezgodność przepisu prawa wewnętrznego z EKPCz); L.K. Paprzycki, Samodzielność jurysdykcyjna sądu karnego (wybrana problematyka europejska), „Europejski Przegląd Sądowy” 2014, nr 1, s. 73. Odmiennie, jak się wydaje, Z. Świda, D. Świecki, Komentarz do art. 540 kodeksu postępowania karnego, (w:) Kodeks postępowania karnego. Komentarz, J. Skorupka (red.), wersja elektroniczna, Legalis 2014, teza 15. 
parcie tej tezy jest szerokie rozumienie pojęcia ,potrzeba” użytego w art. $540 \S 3$ k.p.k. oraz zapobieżenie wydaniu kolejnego orzeczenia ETPCz przeciwko Polsce, stwierdzającego fakt naruszenia Konwencji. Wskazuje się zatem, że chodzi o sytuacje, gdy orzeczenie, na które powołuje się skazany w swoim wniosku o wznowienie ,stanowi odzwierciedlenie konsekwentnej linii orzecznictwa strasburskiego albo wydane zostało przez Wielką Izbę" ". Inni wiążą potrzebę wznowienia poza sprawą główną z procedurą wyroku pilotażowego ${ }^{10}$.

Jest też wyrażany pogląd, zgodnie z którym nawet orzeczenie ETPCz wydane przeciwko innemu pozwanemu państwu może stanowić podstawę wznowienia postępowania karnego, o którym mowa w art. $540 \S 3$ k.p.k. ${ }^{11}$ To stanowisko budzi istotne zastrzeżenia w kontekście celu, jakiemu służy podważenie prawomocnego orzeczenia przy zastosowaniu omawianej podstawy prawnej. Jest nim wykonanie judykatu ETPCz, zaś z art. 46 ust. 1 Konwencji jednoznacznie wynika, że państwa strony są zobowiązane wykonać wyroki wydane w sprawach skierowanych przeciwko nim, a nie innym państwom-stronom Konwencji. Przepis ten stanowi bowiem, że państwa są zobowiązane ,do przestrzegania ostatecznego wyroku Trybunału we wszystkich sprawach, w których są stronami" 12 . Już ten argument, samodzielnie, podważa dopuszczalność wznawiania postępowań karnych z powodu orzeczenia Trybunału strasburskiego wydanego przeciwko innemu państwu-stronie Konwencji. Ponadto trzeba podkreślić, że również wyroki Wielkiej Izby Trybunału i zawarta w nich wykładnia postanowień Konwencji są zdeterminowane przez okoliczności faktyczne i prawne konkretnej rozpatrywanej sprawy. Toteż odnoszenie konkluzji takiego wyroku o naruszeniu postanowień EKPCz do polskiego systemu prawnego jest zawsze obarczone dużym ryzykiem pomyłki.

Wracając do zasadniczego problemu, warto rozważyć, co ma przesądzać o ,ppotrzebie" wznowienia innego postępowania karnego niż to, które zostało ocenione przez ETPCz jako naruszające postanowienia Konwencji. Chyba poza sporem pozostaje, że w takim przypadku potrzeba wznowienia postępowania karnego nie może wynikać ze związania konkretnym orzeczeniem ETPCz. Zakres tego związania określa bowiem sama Konwencja w art. 46 ust. 1 i nie budzi wątpliwości w doktrynie, że orzeczenie ETPCz w odniesieniu do potrzeby przywrócenia stanu poprzedniego wiąże inter partes, a nie erga omnes. Wskazuje się bowiem, że zakres

9 Tak: S. Zabłocki, Wznowienie..., op. cit., s. 32.

10 Tak: B. Nita, Orzeczenie..., op. cit., s. 7.

11 Tak: B. Nita, Orzeczenie..., op. cit., s. 7; P. Hofmański, (w:) Konwencja o Ochronie Praw Człowieka i Podstawowych Wolności, t. II, L. Garlicki (red.), Warszawa 2011, s. 393.

12 Przeciwko dopuszczalności wznowienia postępowania w takim przypadku opowiadają się: A. Sakowicz, (w:) K.T. Boratyńska, A. Górski, A. Sakowicz, A. Ważny, Kodeks postępowania karnego. Komentarz, Warszawa 2014, s. 925; P. Hofmański, E. Sadzik, K. Zgryzek, Kodeks..., op. cit., t. III, s. 391; M. Wąsek-Wiaderek, Samodzielność..., op. cit., s. 388; W. Grzeszczyk, Kodeks postępowania karnego. Komentarz, Warszawa 2014, s. 728. Tak też: postanowienie Sądu Najwyższego z dnia 5 grudnia 2012 r., III KO 64/12, w którym SN oddalił wniosek o wznowienie postępowania stwierdzając, że „postawą wznowienia nie mogą być rozstrzygnięcia organu międzynarodowego wydane w sprawie przeciwko innemu państwu niż Polska”; podobnie: postanowienie SN z dnia 25 marca 2009 r., V KZ 13/09, oba orzeczenia dostępne w bazie orzeczeń „Supremus”. 
obowiązku wykonania wyroku strasburskiego jest wyznaczony granicami podmiotowymi i przedmiotowymi sprawy rozstrzyganej przez Trybunał ${ }^{13}$. Toteż $\mathrm{w}$ procedurze rozpoznania wniosku o wznowienie postępowania karnego odwołującego się do orzeczenia ETPCz wydanego w innej sprawie orzeczenie to nie może być uznane za prejudykat ${ }^{14}$. Warto $\mathrm{w}$ tym względzie rozważyć specyfikę wyroku pilotażowego lub quasi-pilotażowego. Czy rzeczywiście wznowienie poza sprawą główną jest potrzebne dla sprostania wyzwaniom wynikającym z wykonania wyroku pilotażowego? Jak wynika $\mathrm{z}$ art. 61 Regulaminu Trybunału ${ }^{15}$, wyrok pilotażowy ze swej natury ma zasięg wykraczający poza sprawę główną, jego zadaniem jest ,pilotowanie” całej grupy podobnych spraw zawisłych już przed ETPCz. W art. 61 ust. 3 Regulaminu wskazuje się, że w wyroku pilotażowym Trybunał określa zarówno „charakter problemu strukturalnego lub systemowego bądź innej ustalonej dysfunkcji, jak i typ środków naprawczych, które podjąć ma zainteresowana Układająca się Strona na szczeblu krajowym na mocy sentencji wyroku". Przepis art. 61 ust. 4 Regulaminu ustanawia kompetencję Trybunał do wskazania terminu na podjęcie środków naprawczych, zaś stosownie do art. 61 ust. 6a Regulaminu, Trybunał może odroczyć rozpoznanie wszelkich podobnych skarg do czasu przyjęcia środków naprawczych wymaganych na mocy sentencji wyroku pilotażowego.

Z przytoczonych uregulowań wprost wynika, że sentencja wyroku pilotażowego zawiera wskazanie środka naprawczego. Toteż jeżeli Trybunał wskazałby na wznowienie postępowania karnego jako konieczny środek naprawczy w sentencji wyroku pilotażowego, to oczywiście takie rozstrzygnięcie wiązałoby sąd karny rozpoznający wniosek o wznowienie postępowania na podstawie art. $540 \S 3$ k.p.k. Trzeba jednak podkreślić, że potrzeba wznowienia wynikałaby wówczas z rozstrzygnięcia, któremu sam Trybunał nadał skutek wykraczający poza sprawę główną (pilotażową). Również zakres podmiotowy tego wznowienia określałby wiążący sąd karny wyrok ETPCz. Jak bowiem wynika z art. 61 Regulaminu, możliwe są co najmniej dwie opcje: 1) wskazanie w sentencji wyroku pilotażowego na potrzebę wznowienia wszystkich postępowań karnych, co do których wniesione zostały już skargi indywidualne, a Trybunał odroczył ich rozpoznanie do czasu przyjęcia i wdrożenia środków naprawczych lub 2) wskazanie, że należy wznowić wszystkie postępowania karne ujawniające identyczny problem systemowy. I właśnie w zakresie zdefiniowanym w wyroku pilotażowym powinno wówczas nastąpić wznowienie postępowania karnego, w ramach wykonania tego wyroku, o ile zwróci się o to uprawniony podmiot (czyli skarżący, który wniósł już skargę indywidualną do ETPCz lub skazany, w którego sprawie również zaistniał problem systemowy). Paradoksalnie to właśnie

\footnotetext{
13 Por. m.in. P. Grzegorczyk, Skutki wyroków Europejskiego Trybunału Praw Człowieka w krajowym porządku prawnym, „Przegląd Sądowy” 2006, nr 6, s. 11 i 14-15; L. Garlicki, (w:) Konwencja..., op. cit., t. II, s. 354-355. Szerzej swój pogląd uzasadniam, (w:) M. Wąsek-Wiaderek, Samodzielność..., op. cit., s. 388-390.

15 Tekst Regulaminu Trybunału po zmianach wprowadzonych z dniem 1 stycznia 2014 r. jest opublikowany na stronie internetowej ETPCz pod adresem: http://www.echr.coe.int/Pages/home.aspx?p=basictexts/rules \&C=\#n1347875693676_pointer
} 
funkcjonowanie w strasburskim systemie ochrony praw człowieka procedury wyroku pilotażowego przemawia przeciwko wznawianiu postępowania karnego poza sprawą główną wówczas, gdy Trybunał wydał jedynie wyrok „klasyczny”. Przepis art. 61 ust. 1 Regulaminu stanowi bowiem, że Trybunał może uruchomić omawianą procedurę wówczas, gdy stwierdzi istnienie ,,problemu strukturalnego lub systemowego bądź innej podobnej dysfunkcji, która spowodowała lub może spowodować podobne skargi."

Podsumowując ten wątek rozważań trzeba stwierdzić, że dopuszczalne jest wznowienie postępowania karnego na podstawie art. $540 \S 3$ k.p.k. poza sprawą główną wówczas, gdy we wniosku o wznowienie wskazuje się na wyrok pilotażowy, z którego sentencji wynika potrzeba wznowienia postępowania objętego wnioskiem $^{16}$. Dotychczas w żadnej sprawie ,polskiej” Trybunał nie użył procedury wyroku pilotażowego lub quasi-pilotażowego, aby wskazać na dysfunkcję sprawowania wymiaru sprawiedliwości w sprawach karnych, która mogłaby być zniwelowana za pomocą instytucji wznowienia postępowania karnego. Wręcz przeciwnie, wskazując na problem systemowy orzekania przez asesorów, którzy nie spełniali kryteriów „sądu niezawisłego i bezstronnego" z art. 6 ust. 1 Konwencji, Trybunał w uzasadnieniu wyroku Henryk Urban i Ryszard Urban p. Polsce ${ }^{17}$ wprost wyłączył możliwość wznowienia zarówno postępowania karnego, które legło u podstaw skargi strasburskiej, jak i, co do zasady, innych postępowań karnych, w których orzekali asesorzy. Na poparcie tego stanowiska Trybunał odwołał się do swojego wcześniejszego orzecznictwa, zgodnie z którym ,zasada pewności prawa, stanowiąca konieczny element w prawie Konwencji, może zwalniać państwo z podważenia aktów prawnych lub rozstrzygnięć dotyczących sytuacji zaistniałych przed datą wydania wyroku Trybunału stwierdzającego niezgodność prawa krajowego z Konwencją"18.

Kolejny argument na poparcie tezy o potrzebie wznawiania postępowań karnych nieobjętych klasycznym orzeczeniem strasburskim odwołuje się do potrzeby zapobieżenia stwierdzaniu przez Trybunał naruszeń Konwencji w przyszłości w podobnych sprawach. Punktem wyjścia do ustosunkowania się do tego argumentu musi być udzielenie odpowiedzi na pytanie, czy wykładnia postanowień Konwencji zawarta w orzeczeniu ETPCz działa wstecz, a zatem posiada moc wiążącą ex tunc, czy też jedynie prospektywnie. W doktrynie prawa międzynarodowego przyjmuje się, że odpowiedzialność państwa za naruszenie standardów określonych w konwencjach regulujących ochronę praw człowieka skutkuje zobowiązaniem do: 1) zaprzestania naruszenia, jeżeli ono nadal trwa; 2) podjęcia środków w celu zapobieżenia ponownemu naruszeniu, jeżeli wymagają tego okoliczności; 3 ) naprawienia szkody,

16 Taki pogląd wyraziłam już uprzednio: M. Wąsek-Wiaderek, Samodzielność..., op. cit., s. 385.

17 Wyrok z dnia 30 listopada 2010 r., skarga $\mathrm{nr} 23614 / 08, \S 65$.

18 "...the Court recalls its case-law according to which the principle of legal certainty, which is necessarily inherent in the law of the Convention, may dispense States from questioning legal acts or situations that antedate judgments of the Court declaring domestic legislation incompatible with the Convention." (§ 65 wyroku). 
obejmującego, o ile to możliwe, restitutio in integrum. W tym względzie doktryna nawiązuje do zasad międzynarodowej odpowiedzialności państwa na gruncie prawa międzynarodowego, przyjętych przez Komisję Prawa Międzynarodowego w $2001 \mathrm{r}$. (Artykuły 30-34) ${ }^{19}$. Wobec tak zakreślonych obowiązków, oczywiste jest, że restitutio in integrum najpełniej może być osiągnięte przez powtórzenie postępowania karnego w sprawie, której dotyczył wyrok strasburski ${ }^{20}$. W odniesieniu do wszystkich innych spraw poza sprawą główną, uaktualnia się tylko jedna dyrektywa wynikająca z wymienionych obowiązków, mianowicie zapobieżenie powtórzeniu podobnych naruszeń praw człowieka w przyszłości. Sądy karne mogą ten cel osiągnąć głównie na dwa sposoby. Po pierwsze przez stosowanie zgodnej z orzeczeniem ETPCz wykładni postanowień Konwencji we wszystkich rozpatrywanych sprawach oraz, po drugie, przez ewentualne uruchomienie dostępnych im procedur wyeliminowania z systemu prawa przepisu sprzecznego z Konwencją. Obowiązek wykonania wyroku strasburskiego w obrębie zapobieżenia podobnym naruszeniom praw człowieka działa jedynie prospektywnie i nie skutkuje potrzebą wzruszania prawomocnych orzeczeń kończących postępowania karne przed wydaniem wyroku ETPCz, o ile nie ma on charakteru pilotażowego. Klasyczne orzeczenie strasburskie nie posiada bowiem mocy wiążącej ex tunc ze skutkiem w postaci obowiązku uchylenia prawomocnych rozstrzygnięć zapadłych przed jego wydaniem i ujawniających podobne naruszenie Konwencji. Wydanie przez ETPCz orzeczenia identyfikującego naruszenie Konwencji powinno natychmiast spowodować zmianę stosowania prawa we wskazanym w nim kierunku, tak aby nie dochodziło do podobnych naruszeń dających podstawę do wnoszenia skarg do ETPCz.

W mojej ocenie wyłączenie dopuszczalności wznowienia poza „sprawą główną" nie powoduje ryzyka stwierdzenia przez Trybunał podobnych naruszeń Konwencji w innych sprawach, o ile sądy karne będą prawidłowo reagowały na orzeczenia strasburskie. Jeżeli postępowanie karne w innej sprawie nie zakończyło się prawomocnym rozstrzygnięciem przed wydaniem wyroku ETPCz identyfikującym naruszenie Konwencji, to wyrok ten powinien spowodować wskazane powyżej skutki jeszcze w toku rozpoznania tej innej sprawy. Jeżeli zaś wyrok ETPCz przesądzający ewentualnie o ,potrzebie" wznowienia postępowania został wydany po prawomocnym zakończeniu innych postępowań karnych, w których wystąpiło identyczne naruszenie,

19 Articles on responsibility of states for international wrongful acts, przyjęte na 53. posiedzeniu Komisji Prawa Międzynarodowego; dostępne pod adresem: http://www.un.org/law/ilc/ (data dostępu: 1 kwietnia 2014 r.). Obszernie o dopuszczalności wykorzystania Artykułów w odniesieniu do odpowiedzialności państwa za naruszenie praw człowieka w stosunku do podmiotów niepaństwowych: E. H. Morawska, Zasady międzynarodowej odpowiedzialności państw za naruszenia praw człowieka dokonane przez podmioty niepaństwowe. Autonomiczność koncepcji Europejskiego Trybunału Praw Człowieka, (w:) Wpływ Europejskiej Konwencji Praw Człowieka na systemy ochrony praw człowieka oraz międzynarodowe prawo karne i humanitarne, E. Karska (red.), Warszawa 2013, s. $127-130$.

20 Por. D. Forst, The Execution of Judgments of the European Court of Human Rights. Limits and Ways Ahead, „Vienna Journal on International Constitutional Law, 2013, vol. 7, nr 3, artykuł dostępny na stronie internetowej czasopisma pod adresem: http://www.icl-journal.com/download/f1527ce403500a9ec58b8269a9a91471/ICL_ Thesis_Vol_7_3_13.pdf (dostęp: 24 marca 2014 r.), s. 6-7. 
to $\mathrm{z}$ reguły oskarżeni nie będą mogli skutecznie wnieść skargi indywidualnej w tych sprawach. Warunkiem dopuszczalności skargi jest bowiem wyczerpanie krajowych środków odwoławczych. Przyjmuje się zatem, że zarzut sformułowany w skardze (np. naruszenia prawa do rzetelnego procesu w określony sposób) musi być wcześniej podniesiony przed sądami krajowymi. Ten wymóg, kluczowy dla realizacji zasady subsydiarności systemu strasburskiego, zazwyczaj nie będzie spełniony, jeżeli skarżący dowie się o naruszeniu jego praw konwencyjnych właśnie z wydanego wyroku ETPCz. Toteż ryzyko stwierdzenia przez Trybunał podobnych naruszeń w przyszłości dotyczy wyłącznie tej grupy spraw, w których skarżący w toku prowadzonych wobec nich postępowań karnych podnosili zarzut naruszenia postanowień Konwencji, nie został on uwzględniony przez sądy krajowe, w tym Sąd Najwyższy (skoro wniesienie kasacji z zasady jest wymagane dla spełnienia formalnych warunków dopuszczalności skargi) i jednocześnie został wydany wyrok ETPCz w innej sprawie, potwierdzający zasadność ich zarzutów sformułowanych na podstawie Konwencji. Dopuszczając wznowienie postępowań karnych w tej grupie spraw nie zapobiega się jednak powstaniu naruszeń praw człowieka w przyszłości (do czego państwo jest zobowiązane w ramach wykonania wyroku), a jedynie zapobiega się orzeczeniu naruszenia Konwencji przez Trybunał w odniesieniu do postępowania karnego prowadzonego i prawomocnie zakończonego przed wydaniem orzeczenia o naruszeniu praw człowieka przez ETPCz.

„Prognostyczne” wznawianie postępowań karnych w celu zapobieżenia wydaniu orzeczenia ETPCz stwierdzającego naruszenie Konwencji dopuszczono w niektórych systemach prawnych państw - członków Rady Europy. Bardzo interesujące rozwiązanie prawne przyjęto w tym względzie w Mołdawii. Mołdawski kodeks postępowania karnego reguluje samodzielną przesłankę do wzruszenia prawomocnego wyroku w celu korekty naruszeń prawa wówczas, gdy Europejski Trybunał Praw Człowieka poinformuje rząd o wniesieniu skargi indywidualnej zarzucającej pogwałcenie praw konwencyjnych. To absolutnie nowatorskie rozwiązanie prawne ma służyć ułatwianiu zawierania ugód ze skarżącymi po ,zakomunikowaniu” skargi rządowi, a przed jej merytorycznym rozpoznaniem. Obserwacja praktyki orzeczniczej ETPCz prowadzi bowiem do wniosku, że przekazanie skargi rządowi do ustosunkowania się jest przeprowadzane po dokonaniu wstępnej oceny, że skarga nie jest niedopuszczalna, co obejmuje także wstępne wykluczenie jej oczywistej bezzasadności. Zgodnie z art. 452 mołdawskiego k.p.k., wniosek o ponowne rozpoznanie sprawy $\mathrm{z}$ omawianego powodu może być wniesiony w terminie 6 miesięcy od daty ,zakomunikowania” skargi rządowi, a właściwy do jej rozpoznania jest Sąd Najwyższy ${ }^{21}$.

21 Do mołdawskiego kodeksu postępowania karnego podstawa wznowienia postępowania w celu wykonania wyroku strasburskiego została wprowadzona ustawą nr 66 z dnia 5 kwietnia 2012 r., obowiązującą od dnia 27 października 2012 r. Oprócz wskazanej powyżej przesłanki, zgodnie z art. 4641 mołdawskiego k.p.k., wznowienie postępowania karnego może nastąpić wskutek stwierdzenia przez ETPCz naruszenia praw zagwarantowanych 
Zdecydowana większość orzeczeń Sądu Najwyższego w przedmiocie wniosków o wznowienie postępowania karnego złożonych na podstawie art. $540 \S 3$ k.p.k. dotyczyła spraw karnych, które były przedmiotem skargi strasburskiej ${ }^{22}$. Jedynie w 5 spośród 18 dotychczas rozpoznanych wniosków nie wskazano na orzeczenie ETPCz zapadłe w sprawie, której dotyczył wniosek o wznowienie. Trzy wnioski nie wskazywały konkretnych judykatów strasburskich, a jedynie odwoływały się w sposób ogólny do orzecznictwa Europejskiego Trybunału Praw Człowieka, w związku $\mathrm{z}$ czym nie zostały uwzględnione ${ }^{23}$. W jednym $\mathrm{z}$ nich wskazano na orzeczenia wydane przeciwko innym państwom - członkom Rady Europy jako źródło zaistnienia „potrzeby” wznowienia postępowania karnego ${ }^{24}$. W dwóch kolejnych sprawach Sąd Najwyższy zajął różne stanowisko co do dopuszczalności wznowienia postępowania karnego poza sprawą główną. W postanowieniu z dnia 27 września 2013 r. stwierdził, że „podstawą wznowienia postępowania karnego, określoną w art. $540 \S 3$ k.p.k., może być jedynie rozstrzygnięcie organu międzynarodowego zapadłe w sprawie i w odniesieniu do osoby, których wniosek dotyczy"25. Z kolei postanowieniem z dnia 16 lipca 2013 r. Sąd Najwyższy również oddalił wniosek o wznowienie postępowania karnego poza „sprawą główną”, ale jednocześnie nie wykluczył możliwości wzruszenia prawomocnego rozstrzygnięcia wydanego w innej sprawie niż objęta judykatem strasburskim ${ }^{26}$.

Nie ma wątpliwości, że sposób ujęcia przesłanek wznowienia postępowania sądowego w art. $540 \S 3$ k.p.k. pozwala zarówno na wąską, jak i szeroką wykładnię tego przepisu. I tak powinno pozostać, gdyż ma on stanowić podstawę prawną dla wykonania różnych rozstrzygnięć organów międzynarodowych, w tym tych, które posiadają moc wykraczającą poza ramy jednostkowej sprawy lub nawet erga omnes. Jeżeli jednak uwzględni się cel art. $540 § 3$ k.p.k., to zasadne jest przyjęcie, że zakres podmiotowy wznowienia postępowania karnego na tej podstawie prawnej jest każdorazowo zdeterminowany mocą wiążącą rozstrzygnięcia organu międzynaro-

w Konwencji lub wydania decyzji o skreśleniu sprawy z listy skarg z powodu zawarcia ugody między skarżącym a pozwanym rządem, jeżeli przynajmniej jeden poważny skutek naruszenia Konwencji nadal trwa i nie może być zniwelowany w inny sposób niż przez wzruszenie prawomocnego orzeczenia. Przepis ten wyraźnie ogranicza krąg podmiotów uprawnionych do złożenia wniosku o wznowienie postępowania do tych, których dotyczyło wydane przez ETPCz orzeczenie. Wymienia bowiem osobę, której prawo naruszono, najbliższych skazanego (jednak w przypadku jego śmierci osoby najbliższe mogą domagać się wznowienia postępowania karnego wyłącznie na jego korzyść) i prokuratora. Wnioski o wznowienie postępowania karnego z powodu orzeczenia ETPCz mogą być złożone w terminie 1 roku od dnia ogłoszenia tego orzeczenia i są rozpoznawane przez Sąd Najwyższy Mołdawii. Por. raport: Execution of judgments of the European Court of Human Rights by the Republic of Moldova (1997-2012), Legal Resources Centre From Moldova, V. Gribincea (red.), 2012, s. 79-80. Jak wskazuje S. Zabłocki, do dnia 19 października 2012 r. w Izbie Karnej SN rozpoznano łącznie 12 wniosków wznowieniowych złożonych na podstawie art. 540 § 3 k.p.k. (Wznowienie..., op. cit., s. 34). Od tej daty do dnia 1 kwietnia 2014 r. Sąd Najwyższy rozpoznał 6 kolejnych wniosków o wznowienie postępowania karnego. Postanowienie SN z 24 listopada 2005 r., III KO 10/05, Lex nr 164382; postanowienie SN z dnia 5 grudnia 2012 r., III KO 64/12, postanowienie SN z dnia 12 grudnia 2013 r., III KO 77/13, oba ostatnie orzeczenia dostępne w bazie „Supremus”.

24 Postanowienie SN z dnia 5 grudnia 2012 r., III KO 64/12, baza orzeczeń Supremus.

25 Postanowienie SN z dnia 27 września 2013 r., II KO 39/13, baza orzeczeń Supremus.

26 Postanowienie SN z dnia 16 lipca 2013 r., III KO 118/12, baza orzeczeń Supremus. 
dowego. W przypadku wiążących inter partes klasycznych wyroków strasburskich omawiana przesłanka wznowienia postępowania powinna powodować uchylenie prawomocności orzeczenia i powtórzenie postępowania właśnie w sprawie głównej. W przypadku pilotażowych wyroków ETPCz, zakres pożądanego wznowienia postępowań jest określony właśnie w tym wyroku, wiążącym przecież sąd karny.

Zamiast podsumowania warto wskazać na dwa niebezpieczeństwa wynikające z zaaprobowania szerokiej wykładni art. 540 § 3 k.p.k. w odniesieniu do judykatów strasburskich. Pierwsze niebezpieczeństwo wynika z braku terminu na złożenie wniosku o wznowienie postępowania na tej podstawie ${ }^{27}$. Nie ma żadnych przeszkód prawnych do domagania się wznowienia postępowań karnych zakończonych po dniu 1 maja 1993 r., czyli dacie poddania się przez Rzeczpospolitą Polskę jurysdykcji ETPCz. Różnorodność naruszeń Konwencji stwierdzonych dotychczas w kilkuset już wyrokach ETPCz wydanych w odniesieniu do spraw karnych otwiera tu szerokie możliwości dla skazanych. Tytułem przykładu można wymienić powtarzające się $\mathrm{w}$ wielu orzeczeniach stwierdzenie naruszenia art. 6 ust. $1 \mathrm{w}$ zW. z art. 6 ust. 3 lit. c Konwencji z powodu nieuwzględnienia wniosku oskarżonego pozbawionego wolności o doprowadzenie go na rozprawę odwoławczą. To właśnie z powołaniem się na jedno z takich orzeczeń ETPCz w 2013 r. został złożony wniosek o wznowienie postępowania w sprawie zakończonej prawomocnym wyrokiem skazującym w 1999 r. (sprawa II KO 39/13).

Drugie niebezpieczeństwo zostało już zasygnalizowane. Zasadniczo wynika ono z tego, że Trybunał orzeka naruszenie Konwencji na podstawie konkretnych okoliczności sprawy. Owszem, można wskazać na pewne linie orzecznictwa, niemniej jednak i one ulegają niekiedy zmianie. Wobec tego pojawia się pytanie: czy zadaniem sądu orzekającego w przedmiocie wznowienia jest wówczas badanie ,,potrzeby" powtórzenia postępowania karnego na gruncie orzeczeń ETPCz powołanych we wniosku o wznowienie, czy też może sąd karny powinien uwzględnić z urzędu, że po wydaniu judykatów strasburskich wskazanych we wniosku doszło do zmiany wykładni postanowień Konwencji? Dobrego przykładu dostarcza zmiana wykładni art. 6 ust. 3 lit. d Konwencji w odniesieniu do prawa oskarżonego do zadawania pytań „świadkom oskarżenia”. Do wydania wyroku zmieniającego linię orzecznictwa w precedensowej sprawie A-Khawaja i Tahery p. Zjednoczonemu Królestwu ${ }^{28}$ Trybunał dość rygorystycznie przyjmował, że zeznania świadka, któremu oskarżony nie mógł zadawać pytań w toku procesu karnego, nie mogą stanowić jedynego lub „głównego” dowodu przeciwko oskarżonemu. W rezultacie w kilku sprawach polskich stwierdził z tego powodu naruszenie prawa do rzetelnego procesu. We wspomnianym wyroku ETPCz przyjął bardziej elastyczne kryteria oceny rzetelności takiego postępowania. Od tego judykatu w żadnej sprawie polskiej nie zostało rek, Wznowienie..., op. cit., s. 304. Został on zaaprobowany przez S. Zabłockiego (Wznowienie..., op. cit., s. 33). Wyrok Wielkiej Izby z dnia 15 grudnia 2011 r., skargi nr 26766/05 i 22228/06. 
stwierdzone naruszenie art. 6 ust. 3 lit. d Konwencji z omawianego powodu, chociaż zaistniały w nich bardzo podobne okoliczności faktyczne i prawne jak w tych, w których wcześniej Trybunał stwierdził naruszenie Konwencji. Zmiany wykładni postanowień Konwencji nie zdarzają się zbyt często. Mogą one jednak powodować, że sąd karny odwołując się do orzeczeń ETPCz wskazanych we wniosku wznowieniowym uwzględni go i uchyli prawomocne orzeczenie w sprawie, w której w świetle nowej, zmienionej linii orzecznictwa skarżący nie miałby szans na uzyskanie stwierdzenia naruszenia Konwencji przez Trybunał strasburski. „Potrzeba” wznowienia może bowiem wynikać z orzeczeń ETPCz powołanych we wniosku złożonym na podstawie art. $540 \S 3$ k.p.k., ale już nie z najnowszych orzeczeń ETPCz. 


\section{ADMISSIBILITY OF RE-OPENING OF CRIMINAL PROCEEDINGS DUE TO THE JUDGMENT OF THE EUROPEAN COURT OF HUMAN RIGHTS FOUNDING A VIOLATION OF HUMAN RIGHTS IN A SIMILAR CASE}

The article focuses on the interpretation of Article $540 \S 3$ of the Polish Code of Criminal Procedure. Pursuant to this provision, criminal proceedings may be reopened if such a need transpires in the judgment of the European Court of Human Rights. The question is whether this provision may serve as a legal basis for the reopening of criminal proceedings in cases other than the case subject to the judgment of the European Court of Human Rights. The prevailing opinion in the literature, is that the re-opening of other cases outside the main case (assessed by Strasbourg Court) is possible. In this article the Author expresses the opposite opinion. She relies mainly on Article 46 para. 1 of the European Convention on Human Rights and the limited (inter partes) binding force of the judgments of the European Court of Human Rights delivered in an individual case.

Keywords: European Court of Human Rights, re-opening of criminal proceedings, European Convention on Human Rights 